\title{
Barbaridades de los médicos
}

\author{
Doctors do foolishness too!
}

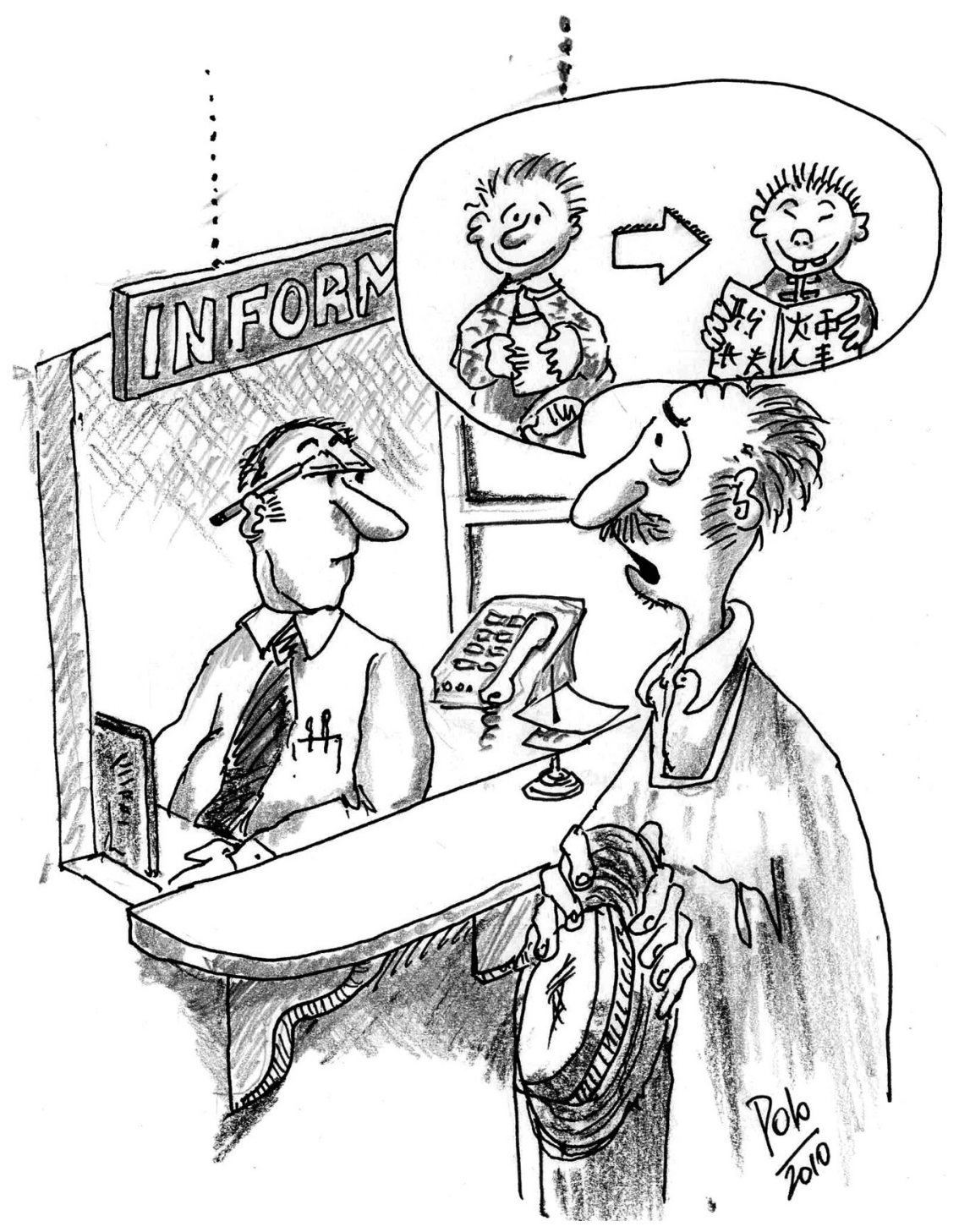

n el Hospital Regional de Temuco fue internado un pequeño de 3 años, de origen rural, cerca de Curarrehue, por un cuadro febril. Al cabo de varios días apareció su abuelo, un humilde campesino, que escasamente se ubicaba en la ciudad.

Llegando al hospital se acercó a una enfermera de pediatría, en el sexto piso, preguntóle por su nieto ¿Y cómo se llama el crío, abuelo?

El anciano la mira esperanzada y responde: Juan $\mathrm{Ne}$ culmán, mi señorita...pero acá le pusieron otro nombre y le dicen "el Kawasaki” (i!)

Carlos Díaz $\boldsymbol{R}$.

Servicio de Pediatría

Hospital Regional Dr. Hernán Henríquez Aravena

Тетисо 